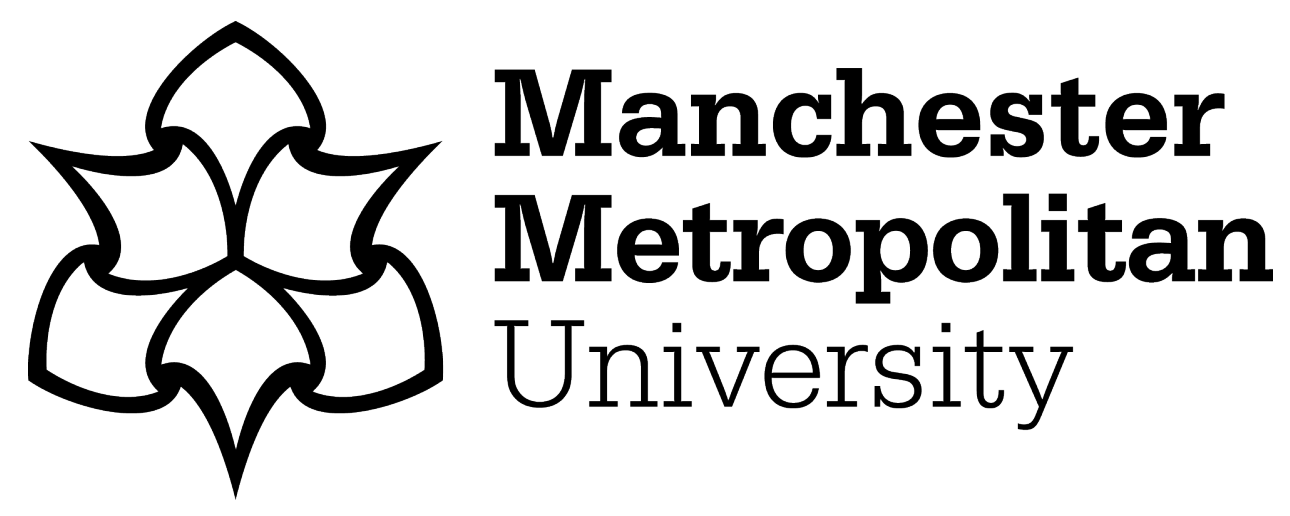

Hackett, AC, Procter, L and Kummerfeld, R (2018) Exploring Abstract, Physical, Social and Embodied Space: developing an approach for analysing museum spaces for young children. Children's Geographies, 16 (5). pp. 489502. ISSN 1473-3285

Downloaded from: https://e-space.mmu.ac.uk/619351/

Version: Accepted Version

Publisher: Taylor \& Francis (Routledge)

DOI: https://doi.org/10.1080/14733285.2018.1425372

Please cite the published version 
Exploring Abstract, Physical, Social and Embodied Space: developing an approach for analysing museum spaces for young children

\author{
Abigail Hackett \\ Manchester Metropolitan University \\ Brooks Building \\ 53 Bonsall Street \\ Manchester \\ M15 6GX
}

Tel: (0161) 2472409

a.hackett@mmu.ac.uk

Lisa Procter

Manchester Metropolitan University

Brooks Building

53 Bonsall Street

Manchester

M15 6GX

Tel: (0161) 2472409

1.procter@mmu.ac.uk

Rebecca Kummerfeld

North Lincolnshire Museum

Oswald road

Scunthorpe

DN15 7BD

rebeccak@gmail.com

We would like to gratefully acknowledge funding from Humber Museums Partnership for this work, as part of the Under Fives in Museums Arts Council Major Museum Partners Award.

Keywords: museums, early childhood, architecture, entanglement 


\section{Abstract}

This paper describes a collaboration between museum staff and university researchers to develop a framework for analysing museum spaces from the perspective of young children. The resultant APSE (abstract, physical, social and embodied) framework draws on spatial theories from childhood studies and architecture to consider children's museum visiting from a spatial perspective. Starting with space not only foregrounds the role places, objects and bodies play in how experiences are constituted, but also resists linearity and predictability of mainstream educational policy discourses about young children's learning. As place, children and objects entangle together, they design and make one another. We draw upon Massey's description of the "chance of space", in which people, objects and places become entangled in unpredictable and unknowable ways, to consider the potential of the APSE framework to offer alternative framings of children in museums. 


\title{
Exploring Abstract, Physical, Social and Embodied Space: developing an approach for analysing museum spaces for young children
}

\author{
Abigail Hackett, Lisa Procter, Rebecca Kummerfeld
}

This paper describes a collaboration between museum staff and university researchers interested in the experiences of young children in museums from a spatial perspective, and interrogates the possibilities and tensions that such an endeavor entailed. The authors were approached by Humber Museums Partnership (HMP), a partnership of local museums in northern England, to develop a framework for analysing museum spaces from the perspective of young children. The resultant APSE (abstract, physical, social and embodied) framework draws on spatial theories from childhood studies and architecture to think about museum spaces for young children (under five years).

A consideration of the spatiality of children's museum visiting is unusual. Place, children and objects become entangled in particular ways when children visit museums. Starting with space not only foregrounds the role buildings, design, objects and bodies play in how experiences are constituted, but also what Massey (2005) has termed "the chance of space", that is, an element of the unknown and of change, that weaves its way through the "routines, rhythms and well-worn paths" of familiar places (112). Within Pink's (2009) notion of emplacement, the world is experienced through sensory entanglements, indivisible from the places that bodies inhabit. In this understanding of children beingin-the-world, the body is not a bounded entity into which sensations pass, but is deeply entangled with and inseparable from the nonhuman world (Ingold, 2008). Nonhuman objects act within these entanglements too. Cautioning against notions of agency that try (and fail) to "express a process of growth and becoming in a language of causation" (97), Ingold describes the entanglement of the human and nonhuman as dance of animacy, in which people, place and things correspond with each other (Ingold, 2013). This correspondence, or slow unfolding of action and experience between human and nonhuman, we suggest, is a useful way to think about how places, objects and children might design and make each other, through the "chance of space".

This perspective of spatial and bodily entanglement between children and place, and the "chance" this throws up, has deep implications how children might experience museums, and how museum practitioners might plan for young children in museum spaces. In this paper, we consider how spatialised thinking about children in museums (through the application of the APSE framework) offered new ways to notice how spaces might be experienced by young children and their families. Coupled with these new insights, we consider the inherent tension in the production of a 'framework' for analysing that which we describe as unknowable, unpredictable. In producing a framework, with 
fixed questions, to be reproduced and distributed, some of the nuances of theory and the openness with which theories can be interpreted in different contexts is lost. However, what is gained, we argue, is opportunities for practitioners to be responsive to the meanings that are co-produced between places, children, objects and things within museum spaces. Overall this paper shows how museum practitioners using the resource gained new insights into the ways in which both material and social interventions (often quite small in scale) can support young children's open-ended experiential production of meaning in and with museum objects and spaces.

\section{Children, museum education and space / place $^{1}$}

Considerations of space and place as aspects of lived experience have a history of offering alternative or digressive readings of everyday life (Lefebvre, 1991; Soja, 1996). Within childhood research, a spatial lens recognises the non-linearity of children's lives, bringing to the fore the complex ways that children's experiences unfold in dynamic exchange with the places they inhabit (Hackett et al, 2015). As such, children's spatialities research tends to sit in juxtaposition to an education policy context in which children continue to be positioned as future beings (James and Prout, 1997) or "communicative (cognitive developmental) project[s]" (in Avineri et al, 2015: 73). Anxiety filled policy rhetoric and popular discourses around the 'proper' development of children has led Clarke (2006) to warn raising children risks being seen as purely "an activity whose purpose is to deliver children with the desired characteristics." (717). Similarly, Olsson (2012) criticises global mainstream early years education as what she terms a standards / accountability movement, which appears to aspire to guarantee fixed outcomes as efficiently as possible, whilst overlooking “children's production of knowledge". An interest in the not-known, and emphasis on the unpredictability of change in young children, stands as critique to notions of 'quality' and generalisable practice with regards to early childhood (Jones et al, 2016). Lenz Taguchi writes "it is impossible for us to know what might be possible for a child or student to learn, to know or become" (Lenz Taguchi, 2010, 16).

Despite an unparalleled development of new museum architecture in recent years (MacLeod, 2005), including galleries and learning spaces dedicated to children (Clore Duffield, 2015), the possibilities for spatial thinking to disrupt assumptions about the 'proper' development of children, and the role of quality and accountability in this, has been little explored in terms of children's museum visiting. How visitors (both adults and children) experience the physical spaces in museums has received much less attention compared to how visitors understand concepts and make meanings in exhibitions (Jones and MacLeod, 2016; Schorch, 2013; Vergeront, 2002). Jones and MacLeod make the case for a greater consideration of museum architecture, arguing

\footnotetext{
${ }^{1}$ For a discussion on the distinction between the terms space and place, see Hackett et al, 2015, p.6-8.
} 
"If we are to take seriously the proposition that visitors are active

participants in the experience of the museum, then we must factor in 'the impact of buildings in terms of their architectural appeal to the emotions' (Forgan 2005: 572).”

Jones and MacLeod, 2016, 213

Vergeront (2002) argues that the physicality of the museum shapes behaviour, and Schorch (2013) has shown that for visitors, embodied sensations in museums and narrated representations are "tightly interwoven dimensions", as his (adult) participants recalled content of the museum through their memories of the space. This small body of work on how the architecture and physicality of museums shapes visitor experience, often in unpredictable ways, alludes to "chance" (Massey, 2005) or unpredictability of experience from a spatial perspective.

Within the collaboration with HMP, we wondered if more nuanced understandings of how children experience the spatiality of museums would offer possibilities to embrace the "chance of space" (Massey, 2005) and the impossibility of knowing what it might be possible for a child to become (Lenz Taguchi, 2010). These questions are critical for practitioners who seek to engage children and families in museums, thus increasing, for example, visiting frequency, learning, engagement or sense of attachment to a place.

\section{Experiencing space; drawing on an interdisciplinary literature}

Our understandings of how children experience space and place draws on the literature from children's geographies (e.g. Skelton and Valentine, 1997; Philo, 2000; Holloway and Valentine, 2000; Kraftl, 2013), anthropology of childhood (Christensen and O’Brien, 2003; Fog Olwin and Gullov, 2003), literacy studies (Leander and Sheehy, 2004), education (Burke, 2013) and architecture (Parnell and Procter, 2011). In particular, two notions from architecture, physical and social use of buildings, and two notions from childhood studies, abstract and embodied experience of space, formed the basis for the APSE framework categories. Each of these categories can be traced theoretically to the work of Lefebvre (1991) but have subsequently been developed differently within their disciplines. In this section, we outline our understandings of the physical, social, abstract and embodied within this interdisciplinary literature, before demonstrating how they fed into the APSE framework.

Lefebvre's (1991) work on the social production of space was amongst the first to consider how space can be both 'perceived' and 'conceived', that is experienced through concrete bodily practices, such as children sat at desks facing a teacher at the front of a classroom, and imagined, described or 
designed through, for example, building plans or curriculum documents. For Lefebvre, the way we imagine space, and the way we act in physical space are "two kinds of space [that] involve, underpin and presuppose the other" (1991: 14). Therefore, from the point of view of children in museums, spatialised thinking does not cast aside what children think, or say, or imagine in museums, but it does understand these things as emerging from, and inseparably entangled with, children's physical experience of the environment through their bodies.

The field of architecture has taken up Lefebvre's (1991) work to better account for the ways in which the use and experience of buildings is always dependent on wider socio-political contexts (Till, 2013). Awan, Schneider and Till (2011) state that 'Lefebvre wrests the production of space from the clutches of specialists, most notably architects and planners, and places it in a much broader social context' (29). Spaces are appropriated, marked and shaped by people and other forces, thus revealing the tensions between "the architect's crystalline conception and a fluid reality" (Ingold 2013, 48). This work has resulted in an interest in power relations that can frame design and occupation of buildings (see for example, Blundell-Jones, Petrescu and Till, 2005), and how spaces and places are made and remade over time (Day and Parnell, 2016; Parnell and Procter, 2011). Applying this thinking to museum architecture, MacLeod (2005) argues for an understanding of museum architecture as "continually reproduced" (10) through use. Increasingly, there is also an interest in tracing how people and nonhuman elements intra act (Armstrong, 2015). Ingold (2013) highlights how the weather marks the materiality of architecture; such processes shift, shape and transcend architectural conceptions of space. As Ingold (2013) writes: "buildings are part of the world, and the work will not stop still but ceaselessly unfolds along its innumerable paths of growth, decay and regeneration" (48). These notions of the physical materials of architecture, itself shifting and transforming over time, in intra action with the social use buildings come to have through their occupation, were taken forward into the APSE framework categories.

Within childhood studies, notions of children's experiences of place as more embodied and more sensory than adults, as having greater intensities of affect, reoccur (Christensen, 2003; Matthews, 1992; Tuan 1977). Christensen's anthropological work on children's experiences of places makes a distinction between spatial knowledge (abstract, generalised, represented in maps) which is important to adults, and emplaced knowledge. For Christensen, emplaced knowledge is "the understanding that emerges from embodied movement through place" (16), and through this embodied movement in place, children attach meanings and memories to place over time. Thus there is a growing theorisation of the production of children's tacit, emplaced forms of knowing place (Bartos, 2013; Leder-Mackley and Pink, 2015; Rasmussen and Smidt, 2003). As Christensen (2003) makes clear, it is not so much that abstract conceptualisations of space are wrong, or should be disregarded, but rather that embodied ways of knowing place should be taken into account along with the abstract, particularly when it 
comes to thinking about how children experience place. This distinction between abstract imagined spaces, and embodied ways of experiencing spaces (which seem particularly pertinent for young children) was taken forward as we developed the APSE framework.

\section{Developing a collaborative approach to thinking about children's experiences of museum spaces}

The APSE framework was developed as a collaboration between the authors and Humber Museums Partnership (HMP) Under Fives in Museums project ${ }^{2}$. Bringing together museum services across three local authorities (North Lincolnshire, East Riding, Hull) in northern England, the HMP Under Fives in Museums project employed three learning officers to focus on under fives audiences, develop new spaces within the museums and launch new early years programmes, initiatives and partnerships over a three year period (2015-2018). The project was ground breaking in the extent to which dedicated museum learning officers focused specifically on children aged under five as a museum audience, an under-researched museum audience, for which interest from the UK museum sector has been growing in recent years (Graham, 2011). The stated aims of the HMP Under Fives in Museums project were to improve provision for Under Fives and their families by identifying and enhancing existing strengths, and undertaking research and consultation to identify areas for development.

At the start of the project, the newly appointed HMP learning officers planned to make a series of visits to sites of good practice for under fives in museums and other visitor attractions across the UK, in order to inform and inspire practice in the Humber region (as recommended in CloreDuffield, 2015). As these visits would inform the development of spaces for under fives in each of the partner museum services, the questions learning officers took with them as they made these visits were:

1. How do I assess or understand what a space is like from the point of view of young children?

2. How can I make decisions about what aspects of practice or spatial design are best for my own setting?

Humber Museum Partnership (HMP) approached the authors to develop a framework for staff to use on these visits, with the aim that observations should be guided by research and theory, and be as useful as possible for informing future practice at HMP. Drawing on the research on children's experiences of places outlined above, a series of research questions were agreed that we hoped the framework would be capable of interrogating:

1. How can sensory, embodied and tacit ways in which people, particularly children, experience places be attended to?

\footnotetext{
${ }^{2}$ We would like to gratefully acknowledge funding from Humber Museums Partnership for this work, as part of the Under Fives in Museums Arts Council Major Museum Partners Award.
} 
2. How can the experience of a place be imagined from the point of view of a young child?

3. How can consultation with young children and their families help give a better understanding of how they experience or what they want from places they visit?

\section{Developing the APSE framework ${ }^{3}$ : Space as abstract and/or embodied, physical and/or social}

The authors met with HMP staff ${ }^{4}$ for a workshop, which began with an introduction to how different disciplines assess and make decisions about space, and how these are informed by the academic literature (as outlined above). Collaboratively, our discussions settled on aspects of this interdisciplinary literature that seemed particularly relevant to the purposes of the project. Being able to observe the architectural design of physical spaces in museums was important, because HMP learning officers would be redesigning their own museums. For example, what sorts of lighting, colours, storage and flooring are good choices for museum spaces for young children? However, as Till (2011) reminds us, 'architecture depends'. Therefore, it was important to consider the (un)expected ways in which families and young children appropriated and used the physical design of museum spaces. How families moved, lingered, enjoyed or ignored certain aspects of museum spaces required consideration. Therefore, we wanted the tool to account for both the abstract (pre-designed) and social use of physical spaces.

As Lefebvre (1991) and so many who have taken up his work remind us, space is never just physical, it is also social. Lefebvre (1991) writes that the social use of spaces is imagined before it occurs. What forms of childhood are being imagined in the museum? What curriculum documents, or assumptions about learning, or interaction, or family, inform how designers and learning officers imagine families and children in their museums? Ultimately, people experience spaces socially and bodily, through their movements in spaces and their interactions with others. This embodied experience of place was also vital to consider if we were to begin to understand museum spaces from the perspectives of young children and families. Christensen's (2003) writing on embodied movement, and meaning becoming attached to place over time, particularly influenced our thinking here.

We worked collaboratively during the workshop, sketching notes related to each category on large sheets of paper, and trying to work with hybridity, in terms of the different ways inter-disciplinary spatial theories have been put to work to think about space. Eventually we arranged the

\footnotetext{
${ }^{3}$ The APSE framework can be downloaded at https://underfivesinmuseums.com/museum-spaces-and-youngchildren/

${ }^{4}$ The staff involved in the APSE project were; Lisa Howarth, Rebecca Kummerfeld, Ros Macaulay, North Lincolnshire Museum Service, Jane Avison and Esther Hallberg, Heritage Learning Hull, Robert Chester, Sarah Hammond, Christine Rostron, East Riding of Yorkshire Museum Service.
} 
abstract/embodied/physical/social categories of space into a grid, giving us four different ways of thinking about children's spatiality (see Figure 1):

1. Abstract physical

2. Embodied physical

3. Abstract social

4. Embodied social

The categories are deliberately overlapping, drawing on different thinking within spatial theories, which are in some cases in dialogue with each other, but in other cases, not delineated or synthesised across different disciplinary approaches (Hackett et al, 2015). These categories are not comprehensive or exclusive. Rather they act as an heuristic for thinking about the different ways in which spaces might be assessed, understood, described or experienced. Working with these four categories as a starting point, by the end of the workshop, we had drafted a range of questions within each of the four spatial categories. The authors took these away and developed them into an analytical framework to guide HMP staff during their visits. Figure 2 gives a more in depth flavour of the sorts of questions encapsulated within each of the four categories.

\section{FIGURE 1}

FIGURE 2

\section{Putting spatial thinking into practice: piloting the APSE framework}

Depending on the nature and purpose of the visit, staff could complete either some sections or all of them, and each category includes general and in depth questions. This was in order to make the framework practical, acknowledging that no one can observe and record everything during every visit. In practice, staff were visiting different sites of good practice for different reasons; perhaps one had a new gallery development, another was well known for running engaging activities, or at another they wanted to observe delivery of a specific staff led session. Therefore, different parts of the framework could be used on different visits.

Over a six month period, HMP staff first used the APSE framework to make reciprocal visits to each other's sites, and then visited nine museums / visitor attractions nationally. The questions in APSE involve a mixture of observations in the space and questions to ask learning staff at the museums visited. By the end of each visit, staff had collected annotated copies of the framework recording a mixture of observations made while walking around museum spaces, through overheard snippets of conversation, information provided by conversations with museum staff, and copies of leaflets and other documentation. 
In developing the APSE framework, we aimed to foreground "the chance of space" (Massey, 2005), that is, the multiplicity of ways in which a space can be experienced, including the unpredictability and know-ability of these experiences. Entanglement between human and nonhuman elements, each of which make and design each other, adds to the futility of trying to pin down or generalise best approaches for planning spaces for children in museums. As such, we sought to vigorously avoid a 'checklist' of best practice or essential features said to determine what makes a space well designed or suitable for young children. In doing so, we align ourselves with the critique within early childhood education of a generalisable notion of quality that may guarantee universal developmental outcomes for all children (Dahlberg and Moss, 2004; Jones et al, 2016; Tobin, 2005). Instead, we concern ourselves with the 'chance' of space (Massey, 2005) and its connection with the impossibility to know what a child visiting a museum might "learn...know....become" (Lenz Taguchi, 2010, p.16). In producing a framework, with fixed questions and directions that can be downloaded and applied by any museum practitioner in any setting, we engage with the inherent tensions between resisting pinning down answers regarding an ideal or failsafe approach to catering for young children in museums, and offering something useful and practical to the museum sector. With this in mind, in the next section, we report on the insights that arose from the pilot, and some of the practical decisions HMP staff made as a result.

\section{Insights and questions arising from the pilot of the APSE framework}

Following the pilot visits, we met again as a group to discuss the insights generated by APSE. We organised a fast and collaborative thematic coding exercise, in which museum staff and researchers explored their observation notes, underlining with different coloured pens anything they noticed recurring frequently, anything that seemed particularly significant, and anything that seemed unusual or surprising ${ }^{5}$. After this, everyone worked towards creating a series of post-it notes, summarising the key observations they had underlined in the resource. We began to lay these post-it notes out on the floor, grouping and sub-grouping according to key categories and themes. Through this process, we noticed that the post-its fell into a number of themes, which opened up lines of discussion, new questions and connections to wider literature and further examples of museum practice. In this next section, we provide a brief sketch of some of these trajectories: dwelling and movement, touch and

\footnotetext{
${ }^{5}$ We introduced a thematic coding exercise despite being aware of the post-structural critique of data coding, in particular its tendency to exclude, fix and introduce hierarchical order too quickly, to subsume difference (MacLure, 2008). MacLure (2008) however, points out that there are benefits of coding, namely a slow entanglement with the data, through which "things gradually grow, or glow" (174). In introducing thematic coding we de-mystified "data analysis", thus opening up a space where practitioners and researchers could entangle together with data, where ideas from the entire data set could take flight, and begin to "grow, or glow".
} 
objects, immersion and activity. In this part of the paper, text in boxes is written from the point of view of the HMP staff (rather than the researchers), summarised by Rebecca Kummerfeld in conversation with the HMP team. By separating this text from our more theoretically orientated reflections relating to the three trajectories, our intention is to allow the reader to engage with the different voices that came together throughout the project; the theoretical reflections of the researchers and the voices of the museum staff orientated towards practical implications. In doing so, we resist our academic voices subsuming those of our partners. The separation of the two texts also reflects the role of the different collaborators in the project; whilst we led on the development of the APSE framework the practitioners ultimately made decisions about how to respond in practical ways to the insights produced. In offering the following observations and related questions, we indicate the potential of a spatialised perspective in general, and the APSE framework in particular, to serve as an heuristic for discussions about children's experience of museum spaces.

\section{What kinds of dwelling and movement would be appropriate for this museum setting?}

Movement emerged very quickly as an important theme during our collaborative analysis.

Observations about how children physically embodied museum spaces included dancing, jumping, running, moving whilst making noises and hand holding between both children and children and grown-ups. Freedom to move seemed important, along with a sense that the route was clear but that families had opportunities to deviate. There seemed to be a relationship between the ways in which children moved through space and the physical qualities of the spaces themselves. For example, lots of natural light, and open spaces offered space for bigger movements, seeming to encourage children to move quickly around, such as running with friends. As Vergeront (2002) writes, "Long halls whisper Run!"' (8).

Exploring the physical elements of a building, including aspects such as lifts and staircases, was significant for families. Things to catch the eye up high or down low, from high ceilings to images on the floor, invited this kind of exploration. In one museum, learning officers observed a toddler leading her dad up and down a set of stairs several times, until dad intervened and moved her on to look at new things. One child walked repeatedly around and around a large elephant skeleton. Another enjoyed looking down from a third floor mezzanine, through the railings to the lower floors. In other spaces, children were observed lying on the floor, playing hide and seek, and crawling on the floor. These kinds of embodied encounters with the physicality of museum spaces seem important for families with young children to feel comfortable and confident in museum spaces. Further, the potential for museums to offer 'spaces to be discovered' enabling particular (social embodied) ways for families to be together to emerge. For example, young children sometimes took the lead in family groups, as has been described previously by Weier (2004) and Hackett (2016). Observations in the 
APSE pilot showed that children could shape families' social experience of space by running around large spaces, climbing up and down stairs, and making repeated movements.

\section{Putting observations into practice at HMP}

Humber Museums Partnership decided to run training for the front-of-house staff on being "underfives friendly". This included practical activities on how young children grow and develop, explaining the importance of movement and exploration. Staff have since reported feeling more confident in welcoming families and encouraging them to explore, move around and make noise. North Lincolnshire Museum also built a buggy park in the courtyard. This allows families to lock their buggies up and explore the museum with greater freedom. An unexpected result of this has been seeing many more child-led visits. Where before, families would often push their younger children through the museum in their buggies, now the children are out and about, dictating the direction and pace of the visit. This also allows greater interaction, movement through and discussion about displays.

Thinking further about the potential for different types of space to offer different types of movement, we identified that physical elements of a space are indivisible from children and families' dwelling practices. Our use of the term 'dwelling' draws on Ingold's (2000) dwelling perspective, which stresses the indivisibility of human and non human worlds, unfolding together through constant movement, so that the:

\footnotetext{
"forms humans build whether in the imagination or on the ground, arise within the current of their involved activity, in the specific relational contexts of their practical engagement with their surroundings" (Ingold, 2010, 10)
}

Thus, the notion of dwelling is related to, not dialogically opposed to, the notion of movement; dwelling in the world always involves movement of one kind or another, a social and embodied experience of physical place. In the APSE observations, a mix of space to both move and explore, and to pause or stop, worked well; different types of spaces provoked different kinds of opportunities for dwelling. Spaces just to slow down and be, including for example, rugs, cushions, soft seating, small enclosed spaces such as alcoves and tents, seemed to prompt a sense of relaxation and comfort. These were often spaces for quieter contemplation and stories, and many inter-generational interactions were 
observed in these kinds of spaces. However, it was also often the case that spaces to slow down were also quite incidental, for example a child sitting curled up against a wall in a long quiet corridor.

These observations reflect the ways in which the embodied physical and social elements of space and the chance of space come together in surprising ways, the material design of spaces (physical abstract) becomes entangled both with children's embodied explorations (physical embodied) and their social encounters (embodied social).

\section{Putting observations into practice at HMP}

Having observed the value of dwelling spaces in other museums, several spaces to slow down were incorporated into the new under fives spaces at North Lincolnshire Museum. The 'under the sea corner' has soft mats, cushions and soft seats. It is furnished with treasure baskets, mirrors and fabric for free play and exploration. This was designed as a safe play space for babies and since opening parents have frequently been observed seated at the side as their babies explore. Toddlers also enjoy peeking into the mirrors and experimenting with the fabric while their parents sit on the soft seating nearby. It is a space where children can play independently, with the safety of knowing their parents are within reach. In addition, the museum now includes a cubbyhole cut into the bottom of a storage cupboard, and lined with soft cushions has become a space for climbing into and hiding. It offers children a place to dwell on their own, to take a break from others. We frequently observe children reading books or playing quietly on their own in this space. Finally, the archaeologist's tent is a cosy space that allows families to dwell together. A textured canopy, soft rug, cushions and a basket with books and soft toys invites families into the space. These three different dwelling spaces/experiences seem to have resulted in families spending more time at the museum.

\section{How can we convey what objects can and cannot be touched? If objects cannot be handled, in what} ways can children encounter objects so that feel they are touching them?

The importance of touching both the architecture of the museum and the objects on display was a significant insight from the APSE pilot. This included a number of examples in which children seemed to experience a sense of touching objects even when they were behind glass. At several different museums, children placed their hands against the glass display cases, saying "touched it". In another example, a young child placed their hands against a glass case containing a porcupine, and commented "touched it, that's a spiky one". The physical embodied and social embodied categories within the APSE framework highlight the importance of considering how children experience 
museum spaces and objects through the body, and sensations of touch seem to be important within this.

Pallasmaa (1998) describes touch as "unavoidably concealed in the sense of vision; as we look so the eye touches the object. This hidden tactile experience determines the sensual quality of the object, and mediates messages of invitation or rejection, home or hostility" (297). Different sensory modes are entangled within haptic experiences. Dudley's (2014) analysis of visitors' experience of opening drawers of objects at the Pitt Rivers museum makes a similar point; opening the drawers seemed to tap into a haptic imagination, where "the eye feels". When museum designers, architects and learning staff design and imagine exhibitions or activities, children's museum experiences are conceived as involving a greater or a lesser degree of touch. Are exhibits on open display or behind glass? Will this staff-led session involve real object handling, replicas to play with, or looking at a distance? The abstract physical and abstract social sections of the APSE framework tap into the way in which museum visiting experiences are imagined before they occur. However, the haptic entanglements we noticed during the APSE pilot observations demonstrate the complexity of planning for bodily experiences of place, including through touch.

\section{Putting observations into practice at HMP}

Each of the HMP museums have developed explorer packs, and we wanted to think about the haptic and an expanded notion of touch within these activities. The resources in the explorer packs offer ways of engaging without touch, by encouraging further exploration of objects and spaces. For example, props such as magnifying glasses have been a useful tool for bridging the gap between touch and sight. The explorer packs also include a teddy with cards that prompt children to 'find teddy a place to wash; a place to sleep; a place to eat', offering an invitation to add to or change the way the children see displays. At the Treasure House in Beverly, the development of a small world play area has been another method for integrating touch through proxy. A felt mat was made to look like the seashore and placed beside an exhibition about the seaside. Baskets with seaside small world play encourage children to explore the idea of playing at the seaside, and gain a tangible experience of the images that made up the exhibition.

Patterson (2011) argues that 'tactile appropriation [of/with space] entails greater familiarity with, or habitual use of, the space' (270-271). Touching spaces/objects can become a significant and repeated part of children's regular visits to museums (Hackett, 2015; MacRae, 2007). As MacRae (2007) argues that 'The passing of objects from person to person brought people together through the 
sensation of the thing itself' (165). Sometimes, however, children's touch can be problematic in museums, as different objects can and cannot be touched, and it can be difficult for both children and families to unpick these rules (Archer et al, 2016). HMP staff were particularly inspired by one of the museums visited that had a policy that 'everything you can reach, you can touch'. Anything that should not be touched was either behind glass, far behind barriers or up high out of reach and things that could be touched were laid within reach.

Rather than any of these solutions to children's touch in museums being offered up as an orthodoxy, the APSE framework categories helped us to think about how spaces and social interactions can be planned for on the one hand (abstract physical and abstract social space), and experienced with the body on the other (physical embodied and physical social space). 'Everything you can reach you can touch' is just one example of how abstract and physical conceptualisations of touch can come together ("your body cannot physically reach those things that I have not envisaged you touching"). Each of these responses to touch in museums is an example of the 'chance' of space (Massey, 2005), the unpredictability of how imagined and bodily experienced versions of space might come together to create something new.

\section{Putting observations into practice at HMP}

We felt that it was important to convey clear messages to children and adults about what can and cannot be touched; this could be done through signs but also through the ways that objects are placed. North Lincolnshire Museum is working towards having all touchable objects within reach. Most objects that cannot be touched are in cases behind glass, or behind barriers. In the 'Iron Stone Cottage', a Victorian cottage integrated into the museum, replica and period objects from the handling collection are arranged as they might have been when the cottage was used in the nineteenth century. Everything in this space is arranged in a way that it can be touched. Initially, we observed families being reluctant to handle these objects, unsure whether or not they could be touched. To encourage families, we installed signs with prompting questions: 'can you pour a cup of tea?'. We also developed a marketing campaign that included images of children playing in the cottage helping families to feel confident exploring and touching this part of the museum. Since putting in these signs and launching the campaign, we have observed many more families playing in this part of the museum.

The use of symbols to show what can be touched has been brought into use at Sewerby Hall, a country house, where objects that both can and cannot be touched may be set within reach. For example, in a period room, some items may be replica objects that can be explored, and others may be collections that cannot. Teddy symbols point families to 'cabinets of curiosity' with drawers of handling objects, 
books and resources to help children explore and experience the rooms. In addition, baskets with resources and objects for under fives were placed at floor level, within reach for small children. This has been observed as another simple way of encouraging children to interact with objects. Once families were initiated into understanding this code, they could clearly delineate what could be touched.

\section{What balance between immersion and activity would be most suitable for the museum?}

The different museums visited during the APSE pilot seemed to sit along a continuum from immersion orientated to activity orientated. Some museum spaces seemed to prioritise immersive experiences, in which the space was positioned as the facilitator and children and families were free to engage with this on their own terms. In contrast, in activity-led spaces, blank walls and concealed storage could support a range of activities led by practitioners. In these cases, the practitioner and / or activity were positioned as facilitator. Discussing the tensions in museum architecture more generally, MacLeod (2005) argues that there is a balance to be met between didactic engagement with objects and ideas, and space for imagination and reflection. Marshall (2005) differentiates between "projective" spaces, most common in museums, in which exhibition elements connect together to convey a message, and "reflective" spaces, more common in galleries, which encourage contemplation of individual work. These balances between aesthetic and didactic, immersion and activity, also seem to be manifested in how museum spaces for children are designed.

The contrast between 'ideas led' and 'experience led' interpretation described by Marshall (2005) can alternatively be understood as differential positioning of humans and objects, within interpretation decisions. Just as with decisions about touch in museums, these choices reflect the sorts of child(hood)s and the kinds of learning being imagined in the design of museum spaces. Is museum learning understood as didactic, socially constructed, and therefore reliant on talk and other humans (adults or staff) for its meaning? Or is it understood as something more experiential, open ended, perhaps involving individual experiences with objects or in place, rather than other people? Rather than a binary, the APSE framework enabled us to think about how physical, embodied, immersive aspects of experience come together with shared social meanings in the museum. One example of how this was manifested was in the development of repeated actions or rituals in family museum visits (see also Hackett, 2016). Parents and museum staff during the APSE pilot often talked about rituals that children chose to repeat on every visit, including visiting particular exhibits or sitting in specific locations. Rituals are rarely foregrounded in abstract conceptualisations of how spaces will be 
designed or used, but are a significant aspects of children's embodied physical and social experiences of museums.

\section{Putting observations into practice at HMP}

Through the APSE pilot we identified that, whether an immersive or activity orientated approach was used, rituals and habits were important for many young visitors, particularly those who visited the sites regularly. At one museum, a dad said that his toddler 'always makes me come in here to see the polar bear when we're in town. He won't let us leave until we've done it.' We discovered that identifying the collections that appeal to under fives and building marketing and activities around these can be more meaningful than trying to tackle the whole museum or develop a space or activity. To do so, HMP decided to identify, through observations and consultation, encounters between places, objects and the children themselves that seemed to hold significance in that they were experienced as enjoyable and repeated by children. Through this process, five place/ object /action experiences were identified as significant to children and families at each museum. In the summer of 2016 the HMP launched the 'Humber 5 Things' campaign. HMP now offers families simple prompts to engage with '5 things', both collections and spaces, through leaflets and marketing. This was a low cost intervention and did not require any alterations to the museum spaces. The open ended '5 things' allow families to spend as much time as they like engaging in them. Children are also prompted to draw or write about doing the '5 things' in a resource pack they can take around the museums.

\section{Conclusion}

"It is precisely where the reach of the imagination meets the friction of materials, or where the forces of ambition rub up against the rough edges of the world, that human life is lived" (Ingold, 2013, 73).

In the above quote, Ingold urges a move beyond a binary between design and making, and repositions both as entangled in the other. In his notion of 'designerly making' (69) the designer / maker's imagination must hurry to keep up with the materials, and anticipate where the materials are going, in a process forever poised between "catching dreams and coaxing materials" (73). Similar 'friction' can be noted in the observations arising from the APSE framework, which move between imagined use of spaces and embodied experience, or between physical architectural design, planned family interactions, and the appropriation of these things by children's and families' embodied entanglements 
with the spaces and with each other. The ways in which children experience museum spaces as abstract or embodied, physical and social, are not fixed or binaries but different ways for thinking about the complexity or "chance" (Massey, 2005) of space. Thus, the usefulness of the APSE framework seems to lie in how it encouraged us to consider movement, touch or immersion, for example, as simultaneously abstract and embodied, physical and social.

The implications of this for the design, analysis or use of museum space with children and families is that curation becomes an ongoing, improvisery process. As the practical responses and changes described by HMP in their own spaces demonstrate, there is no one 'solution' for planning for young children in museum spaces. As place, children and objects come together, they design and make one another. Through the careful observation of these encounters, a form of curation in which micro changes are put into action to continually bring life to museum places and objects, can happen. Thus, resisting the discourse of quality or generalizability within early childhood (Jones et al, 2016), the APSE framework instead offers a potential catalyst for micro-changes that resonate with the unique qualities of each setting. In doing so, APSE's ambition "rubs up against the rough edges of the world" (Ingold, 2013, 73) in that it seems to be a framework of fixed questions uncomfortable with its own fixity, with its potential to be seen as a source of authority.

This article has argued for a spatialised approach to thinking about children's museum visiting, drawing upon theoretical insights from children's geographies, childhood studies and architecture, to foreground, in particular, human / nonhuman entanglement, chance and unpredictability in how lives are lived out through bodily experience of space. The ways in which the APSE observations were put into practice at HMP reflects the significance of the micro in terms of creating the conditions in which place, children and objects come to be entangled together, and the possibilities this opened up. Children and the potentials of their bodies are unknowable (Lenz Taguchi, 2010), with a constant drive for creative production (Olsson, 2013). When children encounter unique spaces and objects on their own terms, the 'chance' of space is flung wide open. 


\section{References}

Archer, L., E. Dawson, A. Seakins and B. Wong, 2016. "Disorientating, fun or meaningful?

Disadvantaged families' experiences of a science museum visit." Cultural Studies of Science Education 11: 917-939.

Armstrong, R. 2015. Vibrant Architecture: Matter as a Codesigner of Living Structures. Walter de Gruyter GmbH \& Co KG.

Avineri, N, E. Johnson, S. Brice-Heath, T. McCarty, E. Ochs, T. Kremer-Sadlik, S. Blum, et al. 2015. “Invited Forum: Bridging the "Language Gap."' Journal of Linguistic Anthropology 25(1): 66-86.

Awan, N., T. Schneider and J. Till, 2013. Spatial agency: other ways of doing architecture. London: Routledge.

Bartos, A. 2013. "Children sensing place" Emotion, Space and Society 9: 89-98.

Burke, C. 2013. A Life in Education and Architecture, Mary Beaumont Medd 1907-2005. London: Ashgate.

Christensen, P. 2003. "Place, space and knowledge: children in the village and the city" In Children in the City. Home, neighborhood and community, edited by P. Christensen, P. and M. O'Brien, 13-28. London: Routledge.

Christensen, P. and M. O'Brien 2003. Children in the City. Home, neighborhood and community, London: Routledge. 
Clarke, K. 2006. "Childhood, parenting and early intervention: A critical examination of the Sure Start national programme." Critical Social Policy 26: 699

CloreDuffield 2015. Space for Learning.

Day, C. and R, Parnell, 2003. Consensus design: Socially inclusive process. London: Routledge.

Dudley, S. 2014. "What's in the Drawer?”, The Senses and Society, 9:3: 296-309.

Fog Olwin, K. and E, Gullov, 2003. Children's Places. Cross-Cultural Perspectives. New York: Routledge.

Hackett, A. 2016. "Young children as wayfarers: learning about place by moving through it", Children and Society 30: 169-179.

Hackett, A. Procter, L. and Seymour, J. (eds.) 2015. Children's Spatialities. Embodiment, Emotion and Agency. Palgrave Macmillan.

Holloway, S. and G. Valentine, G. 2000. Children's Geographies: Playing, Living, Learning. London: Routledge.

Ingold, T. 2000. The Perception of the Environment Essays on livelihood, dwelling and skill, London: Routledge.

Ingold, T. 2013. Making. Anthropology, Archaeology, Art and Architecture. London: Routledge.

James, A. and Prout, A. 1997. Constructing and reconstructing childhood: contemporary issues in the sociological study of childhood ( $2^{\text {nd }}$ edition). London: Routledge Falmer 
Jones, P. and MacLeod, S. 2016. "Museum Architecture Matters." Museums and Society 14 (1).

Jones, L., J. Osgood, R. Holmes, M. Urban, 2016. "Reimagining quality in early childhood", Contemporary Issues in Early Childhood, 17(1): 3-7.

Kraftl, P. 2013. Geographies of Alternative Spaces of Education: Diverse Learning Spaces for Children and Young People. Bristol: Policy Press.

Leander, K. and M. Sheehy 2004. Spatializing Literacy Research and Practice. New York: Peter Lang Publishing.

Leder-Mackley, K., S. Pink, and R. Morosanu, 2015. “Knowing the World Through Your Body: Children's Sensory Experiences and Making of Place”. In Children's Spatialities. Embodiment, Emotion, Agency Edited by Hackett, A., L. Procter and J. Seymour, 21-38. Basingstoke: Palgrave Macmillan.

Lefebvre, H. 1991. The Production of Space. (D. Nicholson-Smith Trans). Malden: Blackwell publishing. (Original work published1974).

Lenz Taguchi, H. 2010. Going beyond the theory / practice divide in Early Childhood Education. Introducing an intra active pedagogy. Oxon: Routledge.

MacLeod, M. 2005. Reshaping Museum Space. Architecture, design, exhibitions. London: Routledge.

MacLure, M. 2013. Classification or wonder? Coding as an analytic practice in qualitative research. R. Coleman, J. Ringrose. In: Deleuze and Research Methodologies. Edinburgh University Press, pp.164-183. 
MacRae, C. 2007. "Using senses to make sense of art: young children in art galleries." Early Years 27:2: $159-170$

Marshall C 2005. "When worlds collide: the contemporary museum as art gallery." In Reshaping Museum Space. Architecture, Design, Exhibitions. Edited by S. MacLeod, 185-201. London: Routledge.

Massey, D. 2005. For Space. London: Sage.

Matthews, M. 1992. Making Sense of Place: Children's Understanding of Large-Scale Environments. Barnes and Noble.

Olsson, L. 2012. "Eventicizing Curriculum. Learning to Read and Write through Becoming a Citizen of the World." Journal of Curriculum Theorizing 28 (1).

Olsson, L. 2013. “Taking Children's Questions Seriously: the need for creative thought.” Global Studies of Childhood 3 (2).

Pallasmaa, J. 1998. "Logic of the image". The Journal of Architecture, 3(4): 289-299.

Parnell, R. and Procter, L. 2011. "Flexibility and Placemaking for Autonomy in Learning" Educational and Child Psychology 28 (1): 77-88.

Philo, C. 2000. ““The Cornerstones of My World”: Editorial Introduction to Special Issue on Spaces of Childhood." Childhood 7(3): 243-256.

Pink, S. 2009. Doing Sensory Ethnography. London: Sage. 
Rasmussen, K. and Smidt, S. 2003. „Children in the neighborhood: the neighborhood in the children.” In Children in the City. Home, neighborhood and community. Edited by Christensen, P. and M. O'Brien, 82-100. London: Routledge.

Schorch, P. 2013. "The experience of a museum space." Museum Management and Curatorship, 28:2, 193-208.

Soja, E. W. 1996. Thirdspace: Journeys to Los Angeles and Other Real-and-Imagined Places, Massachusetts: Blackwell Publishers.

Skelton, T. and G. Valentine, G. 1997. Cool Places: Geographies of Youth Cultures. London: Routledge.

Till, J. 2013. Architecture Depends. MITT Press

Tobin, J. 2005. "Quality in Early Childhood Education: An Anthropologist's Perspective.” Early Education \& Development 16(4).

Tuan, Y.-F., 1977. Space and Place: the Perspective of Experience. University of Minnesota Press, Minneapolis.

Vergeront, J. 2002. "Shaping Spaces for Learners and Learning." Journal of Museum Education, 27:1: 8-13.

Weier, K. 2004. "Empowering young children in art galleries, letting them take the lead" Contemporary Issues in Early Childhood 5(1): 106-116. 